\title{
TEACHING AND LEARNING ENGLISH IN A SECOND \\ LANGUAGE SITUATION: THE CASE OF SOME IGBO TEACHERS AND STUDENTS
}

\author{
Nkoli Nnyigide* \& Obiageli Anyaegbu* \\ http://dx.doi.org/10.4314/og.v16i1.10
}

\begin{abstract}
The English language, which is studied as a second language in Nigeria, is indispensable in all spheres of human endeavours. It is the language of government, education, the judiciary and indeed every aspect of national life. All ethnic groups in the country, the Igbo inclusive, embrace this all-important language for their various activities. Because this significant language is not a mother tongue in the Igbo environment, some students of English in a second language situation encounter problems because some learners study it against the background of their mother tongue in which they have attained a reasonable degree of competence. Again, teachers on their own part contribute to the problem owing to their pedagogical incompetence, lack of instructional materials, language interference, etc. To this end, this paper looks at the concept of teaching and learning English in a second language situation with a focus on the problems encountered by the Igbo teachers and learners as regards imbibing the intricacies of the language and possible solution. To get about this, fifty Year one Sandwich students of Department of English Language and Literature, Nnamdi Azikiwe University and their lecturers were directly observed in a classroom situation. It was discovered that they have interference problem amongst other problems inherent in studying English as a second language.
\end{abstract}

\section{Introduction}

It is a truism as affirmed by Eyisi that in Nigerian society, the major yardstick for admission into the select group of the educated is one's performance in the English language. It is also indisputably true that the bastion of education, in the view of the majority of Nigerians, is the establishment, in the learners, of a high level of competence and proficiency in English (57). 
Nnyigide \& Anyaegbu: Teaching and Learning English in a Second Language

Situation...

In virtually all sectors in Nigerian environment, the English language is revered. English is so important in the country that the ability to speak, read and write it becomes the mark of elitism. It is seen as a key to success in the African society. English occupies an enviable position in the Nigerian education system because of the following as pointed out by Azikiwe:

1. Some Nigerian languages are neither literary nor international ones; hence, there are very few reading materials for the child to read in his own language in different disciplines.

2. Learning in Nigerian languages could not open up to the child the ideas and cultures of the world's civilization.

3. There are too many languages in the country. They are estimated to be about 400 languages spoken in Nigeria (26).

The English language is undoubtedly significant as the language of instruction in practically the entire school system, from the upper primary to the highest tertiary level. It is, therefore, the language of education. Apart from the very elementary level of schooling, English becomes the medium of instruction and a subject in the curriculum. The National Policy on Education leaves no one in doubt about this, 'Government will see to it that the medium of instruction in the primary school is initially the mother tongue or the language of the immediate community and, at a later stage, English' (13). But unfortunately, it has been observed that in most schools in the Igbo society, this policy is never implemented. Also, the objectives of the English curricula as contained in the language syllabus mentioned by Azikiwe are:

a. Provide students with a sound linguistic basis for further learning in secondary, tertiary, and vocational institutions.

b. Equip school leavers with a satisfactory level of proficiency in English language usage in their places of work.

c. Stimulate a love of reading as a pleasurable activity.

d. Promote the art of spoken English as a medium for national and international communication. 
e. Enhance and develop further the various skills and competencies already acquired at the primary and junior secondary levels (18). These crucial objectives of the English curricula if all attained will undoubtedly enable the students to acquire communication skills for their future lives occupations.

Commenting on the status of English as a second language, Banjo maintains that 'It plays a very key function in the social, professional, and educational life of Nigeria (3). Indeed, to be regarded as an educated Nigerian, according to Banjo, some level of proficiency in English is required. He justifies this as follows:

If an educated man is defined in Nigeria as one who has at least secondary education, then no Nigerian who speaks no English can be regarded as being educated. The reason for this should be obvious; English is a key subject and the medium of instruction before the end of the primary level (15).

The growth of the English language in the Igbo society is indeed on the increase. The number of young people who register the subject in examinations such as WASC or JAMB as well as undergraduates who undertake The Use of English 1 (GSS101) and The Use of English 11 (GSS 102) as compulsory Use of English in our universities is alarming. According to Wikipedia (2020) there are sixty-eight NUC approved universities in Nigeria. Students cannot graduate in these universities without a pass in the Use of English courses. This study examines the problems encountered by some year one Sandwich students of Igbo Department, Nnamdi Azikiwe University, Awka and their language teachers in studying English as a second language.

The English language is valued because proficiency in it is seen to be indispensable to participating in and benefiting from modern development in all its forms. The burning desire of the majority of Nigerians to acquire this all-important language is based on the fact that it has gained a desirable position in the nation. The English language which occupies an enviable position in the Igbo society has influenced it in some significant ways. This, however, 
Nnyigide \& Anyaegbu: Teaching and Learning English in a Second Language

Situation...

points to the reason why its teaching is compulsory in our education system. The influence of this all-important language in Igbo land is conspicuous in different areas which are discussed inter alia.

\section{Dimensions of the English Language in the Igbo Society Education}

The English language plays conspicuous role in the Nigerian education system. Whenever education is mentioned, the English language comes to the fore. It is thus indispensable and invaluable measuring the quality, efficiency and effectiveness of the school curricular. The English language is pedagogically expressive as the language of instruction in practically the entire school systems from the upper primary to the highest tertiary level. The National Policy on Education supports this fact by maintaining that 'Government will see to it that the medium of instruction in the primary school is initially the mother tongue or the language of the immediate community and, at a later stage, English (13).

The English language is a significant subject in various institutions of learning. This can be seen in the teeming number of young people who register the subject in examinations such as WASC or JAMB as well as undergraduates who undertake GSS 101 (Use of English 1) and GSS 102 (Use of English 11) as compulsory Use of English courses in the universities. To be regarded as an educated Nigerian according to Banjo, some level of proficiency in English is required. He justifies the assertion as follows:

If an educated man is defined in Nigeria as one who has at least secondary education, then no Nigerian who speaks no English can be regarded as being educated. The reason for this should be obvious; English is a key subject and the medium of instruction before the end of the primary level (15).

In most situations in this country, students irrespective of their areas of specialization, take courses in the language. In the West African School Certificate Examination for instance, a poor performance renders the result redundant because one can never gain admission in 
any university with it, the fact that one performed excellently in other subjects notwithstanding. In Nigerian universities, a student who fails the use of English courses can never graduate unless he reregisters and succeeds in the examinations. The greatest asset of the English language is that it is a good instrument of thought and creativity and students are expected to be very proficient or skilled in both the spoken and written forms. Poor knowledge of the English language is thus a clear indication that one may perform poorly in other subjects because examinations in these subjects are expected to be written in English. The incessant desire by the Nigerian government for effective teaching of the language in our schools is rooted on the belief that western education especially a knowledge of the English language would equip them (Youths) with the techniques and skills essential for improvement of personal status in the emergent economic and social structure (Coleman quoted in Eyisi). From the foregoing, therefore, it is germane to emphasize that the English language really influenced the education sector of the Nigerian education system.

\section{Politics}

The political role of the English language in Nigeria started in 1882 when the colonial masters saw the need to train individuals to render sensitive and important government services. The English language plays a vital role in the Nigerian body politics. Candidates for political parties for example read their political manifestoes, print their handbills and posters in English. Inability to speak the language automatically makes the candidate to lose his or her mandate. The 1989 constitution in recognition of the vital role of English in the politics of the country, maintains unequivocally that any candidate for election to the National or State Assembly must have a minimum qualification of a secondary school certificate- a certificate that is rendered almost useless in the absence of a credit pass in English.

The English language played a major role in the fight for Nigerian independence. Various government documents including the constitution of the country are written in English. All the national dailies and political gazettes also appear in English. Without the use of the English language, activities in various government houses in Nigeria would definitely crumble. 
Nnyigide \& Anyaegbu: Teaching and Learning English in a Second Language

Situation...

\section{Sociolinguistics}

In the country Nigeria, there are multiplicities of languages. It is a multi-ethnic, multilingual and multidialectal society. The citizens of the country speak with too many mutually exclusive tongues. In this situation, too many resultant difficulties in communication spring up especially when none of the languages is adopted as a national language. More so any attempt to accept one of the major languages Igbo, Hausa or Yoruba as national languages will dangerously result to ethnic squabble and distrust. When the Hausa language was proposed to be adopted as a second language, it was recorded that Chief Anthony Enahoro vehemently opposed: "As one who comes from a minority tribe, I deplore the continuing evidence in this country that people wish to impose their customs, their languages and even more their way of life upon smaller tribes" (22). Enahoro's view is undisputable owing to the fact that the minority groups will feel cheated. Such a step will be jealously considered as inherently and fundamentally discriminating and domineering on the other minute languages. Giving credence to this Ikiddeh quoted in Eyisi asserts:

A national policy which ignores the interest of minority languages carries a threat of annihilation of those languages and it is an act of political as well as cultural misjudgment (378).

Luckily the introduction and acceptance of the English language as the only official language brought the wrangling controversy to an end. In our country Nigeria today English serves as a lingua franca, that is a language that unifies all the ethnic groups including those with minority languages. It is the only language which any Nigerian from any tribe can use comfortably amidst other tribes. Anyone who could neither speak nor understand the English language will definitely remain uncomfortable when relating to people outside his own ethnic group. Reacting to this, Eyisi succinctly puts:

No one in the country (Nigeria), doctors, lawyers, teachers, engineers, preachers, drivers, traders etc would be able to function effectively without varying levels of communicative competence in English. 
Ogirisi: a new journal of African studies vol. 162020

The reason is that little or no job could be done in the face of so much communication breakdown (7).

The term 'One Nigeria' is strong today because the English language has come to salvage the problem of linguistic diversity.

\section{Mass media and the Legal System}

English is the language of the mass media. The majority of our local and national dailies are printed in the English language. Almost all the programs aired in the television and radio stations are done in the language. The English language has thus dominated every other language in our media houses. It is the only mode of communication which could be used to reach the target number of people within a short time and at a very meager expense. The English language is also the language of the legal profession. All the official law proceedings are done in the language. The implication of this is that a successful lawyer must have some mastery of the English language in order to communicate very well. There may be a problem in the law court when the lawyer fails to use the right vocabulary. Confucius quoted in Eyisi supports this assertion thus:

If the language is not correct, then what is said is not what is meant; if what is said is not what is meant, then what ought to be done remains undone; if this remains undone, morals and arts deteriorate; if morals and arts deteriorate, justice goes astray; if justice goes astray, the people will stand about in helpless confusion. Hence there must be no arbitrariness in what is said. This matters above everything (xi).

This opinion of Confucius points to the fact that whatever is worth doing at all is worth doing well. Lawyers must strive to communicate effectively in the language in order to avoid any form of confusion. Without the English language, most of the cases in our 
Nnyigide \& Anyaegbu: Teaching and Learning English in a Second Language

Situation...

law courts might remain unsettled. So, this all- important language plays an undisputable role in our legal system.

The English language also plays salient roles in our economic system. It is the language of official business. Most business transactions are carried out in English. It becomes evident that English is the only language which gives access to the means of realizing effective economic development. Activities/ transactions in the Central Bank of Nigeria (CBN) as well as other banks are carried out in the English language. All the economic records of the country are kept in no other language than the English language. The English language, therefore, has a great influence in our economy.

It is sad to note that in spite of these copious benefits bestowed on the Nigerian society by English, its teaching in various schools, especially in Igbo states, is hampered by some difficulties which are discussed below:

\section{Problems of Teaching/ Learning English in our Igbo Environment}

Since that the English language is studied as a second language in Nigeria, there are lots of problems emanating from its teaching. These problems are as follows:

\section{The Concept of Interference as a factor}

This occurs when the features of the Igbo language interfere with that of the target language. The English language is a second language in Nigeria. Because the Igbo learner has acquired one or more of the native languages, introducing another language which is alien to him would pose some problems. In a bid to learn the target language, the Igbo learner tends to transfer some features of his own language into the target language. Such interferences can be found at the following levels:

a. Phonological level: The twenty-six letters of the English alphabet are different from the forty-four speech sounds of the English language. This poses a lot of challenges to the Igbo learners of English. Again, the consonant and vowel sounds of the Igbo language are different from those of the English language. Some sounds in the English language do not feature at all in the Igbo 
Ogirisi: a new journal of African studies vol. 162020 language. As a result, learning English as a second language constitutes a big problem to the Igbo learner. Below are the English and the Igbo vowel charts as well as the consonant charts in Figures $1 \& 2$ :

Figure 1: English and Igbo Vowel chart

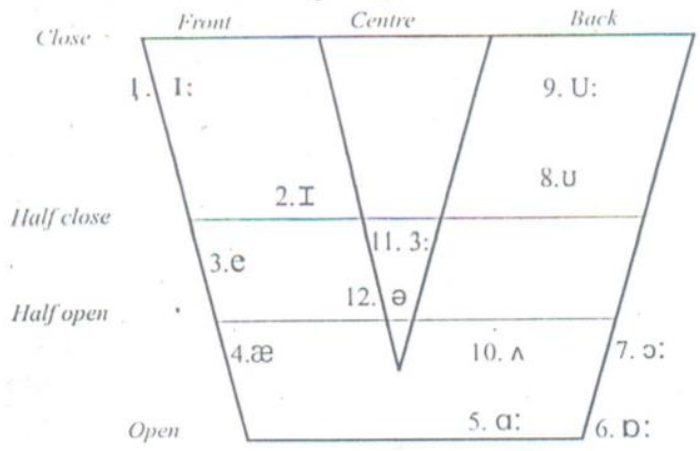

(Eyisi, 210)

Figure 2: English Language Consonant Chart

\begin{tabular}{|c|c|c|c|}
\hline $\begin{array}{l}\text { The Place of } \\
\text { Articulation }\end{array}$ & \multicolumn{2}{|c|}{ The State of Glottis } & $\begin{array}{l}\text { The Manner of } \\
\text { Articulation }\end{array}$ \\
\hline \multirow[b]{2}{*}{$\begin{array}{l}\text { Bilabiai } \\
\text { Alveolar } \\
\text { Velat }\end{array}$} & Voiced & Voiceless & \multirow[b]{2}{*}{$\begin{array}{l}\text { Plosives or } \\
\text { Stop consonants }\end{array}$} \\
\hline & $\begin{array}{l}b \\
d \\
g\end{array}$ & $\begin{array}{l}p \\
i \\
k\end{array}$ & \\
\hline $\begin{array}{l}\text { Liabio-dental } \\
\text { Dental } \\
\text { Aveolar } \\
\text { Palato-alveolar } \\
\text { Glottal }\end{array}$ & $\begin{array}{l}\text { v } \\
\text { z } \\
3 \\
\text { h } \\
\end{array}$ & $\begin{array}{l}\text { i } \\
\theta \\
s \\
s\end{array}$ & Fricatives \\
\hline Palato-alveolar & as & is & Antricates \\
\hline Alveolar & r & & Liquicl \\
\hline Aiveotar & i & & Lateral \\
\hline $\begin{array}{l}\text { Bilabial } \\
\text { Palatal }\end{array}$ & jw & & $\begin{array}{l}\text { Glides or } \\
\text { Semi-vowels }\end{array}$ \\
\hline $\begin{array}{l}\text { Bitabial } \\
\text { Alveotar } \\
\text { Velar }\end{array}$ & $\begin{array}{l}m \\
n \\
0\end{array}$ & & Nasats \\
\hline
\end{tabular}

Looking at Figures $1 \& 2$, one can see clearly the areas of differences in the charts. In the Igbo vowel chart, the vowels $/ \Lambda /$, /3:/, and /ə/ did not feature at all. Words like cup /k $\Lambda \mathrm{p} /, / \mathrm{g} 3: 1 /$, and /ti:t $\int$ / would pose great problems to Igbo learners of English. They would pronounce the words as /koopu/, /gielu/ and /ticha/ respectively. Also, in the consonant charts, the interdental fricatives $/ \theta /$ and /ð/ do not exist at all. This explains why words like think / 
Nnyigide \& Anyaegbu: Teaching and Learning English in a Second Language Situation...

$\theta \mathrm{Ink} /$ and then /ðen/ would constitute a problem to an Igbo student learning English as a second language. They often pronounce the words as /tInk/and/den/ respectively. They mispronounce these words as a result of their mother tongue interference. Because these sounds do not exist in their own language, they simply replace them with what they have in their own language.

\section{b. Grammatical level (morphological and syntactic levels)}

It is a well-established fact that the grammar of any language is the sum total of a competent speaker's linguistic knowledge. Every language has its rule and deviation from such rules leads to incongruous sentences. Because there are rules governing every language, the Igbo learners of English sometimes transfer the rules governing their own language into the English language. Such transfers of constructions are regarded as errors so long as the native speaker is concerned. Sometimes such errors, which are ignored by the ESL teachers, gradually become a permanent feature of the use of English by the Igbo learners. For instance, the sentence 'The woman delivered a bouncing baby girl' is very common among the Igbo speakers of English instead of the correct expression which is 'The woman was delivered of a bouncing baby girl'. The reason for this is that the Igbo version of the sentence is 'Nwaanyi ahụ mụrụ agadaga nwa nwaanyị'. We can analyze it thus:

Nwaanyị ahụ= That woman

Mụrụ= delivered

Agadaga $=$ bouncing

Nwa nwaanyi = A baby girl

Altogether we have: The woman delivered a baby girl.

The above is what we call transliteration. Other examples:

His head is not correct= Isi adighi ya mma. Meaning: He is insane.

Chiamaka knows book well well= Chimaka maara akwụkwọ nke oma nke ọma. Meaning: Chiamaka is intelligent.

c. Orthographic levels: The Igbo L2 learners encounter problems at this level. This is because the Nigerian languages, Igbo inclusive is tonal. What this means is that words are written exactly the same 
way they are pronounced making it a syllabled timed language. Thus we have CVCV or VCVCV as in puta, tinye, okuko, ututu, etc. This is quite different from that of English which is a stress timed language. As a result, the Igbo speakers of English tend to insert a vowel in between the consonant clusters. Words like /ketl/ and /bred/ could be pronounced as /ketụlụ/ and /buredi/ respectively.

d. Lexical levels: This has to do with vocabularies or choice of words coined to represent its equivalent in the English language. For instance, the word 'oga' in Igbo means boss, or one's superior. It is very common for a married woman to refer to her husband as 'oga'.

f. Dialectical levels: At this level, interference is observed as a result of one's dialect. For instance, if an Igbo, a Yoruba or a Hausa speaks English, one can easily decipher the tribe the person belongs to through the dialect.

\section{Pedagogical problems}

The word 'pedagogy' simply means 'teaching'. Pedagogical problems are therefore problems that revolve around the teaching and learning process. They are as follows:

a. Lack of Instructional Material: Instructional materials as recorded in the California Department of Education means all those materials that are designed for use by pupils and their teachers as a learning resource and help pupils to acquire facts, skills, or opinions to develop cognitive processes. Instructional materials are used to help transfer information and skills to others. These are used in teaching in places like schools, colleges and universities. They include language teaching aids like the language laboratory, audio visual and real objects, pictures etc. Unfortunately, some of the schools we have in the country, especially in Igbo land do not have such aids. Where they are available, they may not be enough to go round the students. In some cases, teachers may not know how to use them. Skillful use of instructional materials accelerates students' performances in the classroom. Also, inability to use them hampers learning. 
Nnyigide \& Anyaegbu: Teaching and Learning English in a Second Language Situation...

b. Poor Teaching Method: Teachers often fail to apply language teaching methods like: The grammar-translation methods, the direct method, the audio-lingual method, the cognitive code learning method, communicative language teaching method, the eclectic method, the silent way method, suggestopedia etc. Each of these methods plays salient roles in teaching English as a second language. For example, using Communicative Language Teaching method Ellis and Tomlison, the ESL teacher should have these at the back of his mind:

- Learners learn a language through using it to communicate.

- Authentic and meaningful communication should be the goal of classroom activities.

- Fluency is an important dimension of communication.

- Communication involves the integration of different language skills.

- Learning is a process of creative construction and involves trial and error.

With these at the back of the mind of the language teacher, he should be able to carry the learners along and make them achieve a reasonable degree of competence in the language.

\section{Sociological/ Environmental Factors}

a. The linguistic environment: The English language is used in our Nigerian environment where there is multiplicity of languages. Apart from schools, the different varieties of the language are often used in churches, market place, street etc. Considering the fact that the language is not native to Nigerians, they tend to speak whatever they consider correct so long as communication takes place. To this end, we see and hear different forms of blunders on radio, television programmes, newspapers, books etc.

b. Social Group: Asides the classroom situation, the learner of English as a second language is faced with peer groups, church members and even members of the immediate community. A child who has illiterate parents/ peers that speak bad English would no doubt adopt the debased form of the language. 
4. Psychological factors: This has to do with the atmosphere in which teaching and learning take place. If the environment is unconducive, automatically students would find it difficult to comprehend. Again if the students are bored, tired, hungry etc, affective filter would definitely set in and a good number of them would lack concentration. Self-concept is also another psychological factor, the ability of one to accept one's self is very important in aiding learning.

5. Motivational Factors: Lack of incentives to teachers, lack of motivation on the part of the students. Teachers should be well motivated by the government in order to discharge their duties effectively as regards teaching the language. On the part of the teachers, they should reinforce the students because reinforcement is a powerful tool in language learning. One gets spurred whenever one is appreciated. ESL teachers should not neglect the place of reinforcement in their various classrooms.

\section{Solution}

To solve these problems, the place of the teacher must come to the fore. Looking at the sounds, the teacher should bring out the areas where they differ and drill the students on them.

For instance, the teacher can use minimal pairs thus in teaching:

\section{Vowels}

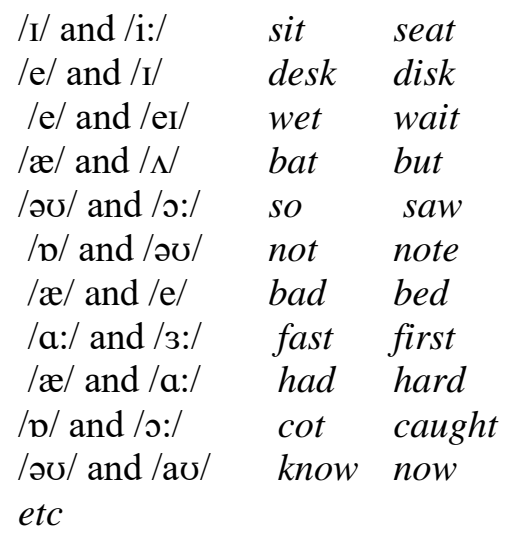




\section{Consonants}

$\begin{array}{lll}/ \mathrm{b} / \text { and } / \mathrm{v} / & \text { berry } & \text { very } \\ / \mathrm{b} / \text { and } / \mathrm{p} / & \text { buy } & \text { pie } \\ / \mathrm{n} / \text { and } / \mathrm{y} / & \text { thin } & \text { thing } \\ / \mathrm{l} / \text { and } / \mathrm{r} / & \text { alive } & \text { arrive } \\ / \mathrm{g} / \text { and } / \mathrm{t} / & \text { catch } & \text { cat } \\ / \mathrm{s} / \text { and } / \mathrm{g} / & \text { sea } & \text { she } \\ / \mathrm{f} / \text { and } / \mathrm{v} / & \text { fan } & \text { van } \\ / \mathrm{f} / \text { and } / \mathrm{h} / & \text { fat } & \text { hat } \\ / \mathrm{f} / \text { and } / \theta / & \text { free } & \text { three } \\ / \mathrm{s} / \text { and } / \theta / & \text { sink } & \text { think } \\ / \mathrm{d} / \text { and } / \mathrm{z} / & \text { with } & \text { whizz } \\ / \mathrm{d} / \text { and } / \mathrm{z} / & \text { page } & \text { pays } \\ / \mathrm{d} / \text { and } / \mathrm{d} / & \text { bad } & \text { badge } \\ \text { etc } & & \end{array}$

Use of teaching materials as well as proper teaching methods must be taken cognizance of. To achieve this, s/he must be proficient because one cannot give what one does not have. For the teacher to bring out the best in the students superbly, s/he must always attend in-service training for professional refurbishment. This will enable him/her imbibe new methods and ideas of teaching the language.

The students on their own part should understand that learning is a continuous process and so strive to achieve excellence in the language. They should endeavour to practice what they learnt bearing in mind that learning is a continuous process.

The government is not left out. They should always have the interest of the teachers at heart and pay them judiciously to enable them discharge their duties effectively. The government should see to it that teachers implement what is contained in the National Policy as regards introducing the mother tongue at the lower primary and at a later stage, English.

\section{Conclusion}

The English language is alien in our Igbo environment. In spite of the "strangeness" of the language, it has a lot of advantages to the 
natives. Despite the benefits of this all-important language in the Igbo society, some Igbo students encounter a lot of difficulties in learning the language. This is because they study it against the background of their mother tongue in which they have attained a reasonable degree of competence. To salvage this problem, teachers of English in a second language situation should study it effectively bringing out the areas where the English language differ from the Igbo language and make the learners to understand. When ESL teachers understand that they are the mirror through which the students see the academic world, they would put in their best to ensure that learners internalize effectively. Learners on their own part should see the language as pleasurable and thus aspire to achieve communicative competence in it. When all these are put into consideration, the problems of the Igbo learners as regards learning English in a second language situation would be nipped in the bud.

\section{*Nkoli Nnyigide, $P h D$}

Department of Igbo Language, Nnamdi Azikiwe University, Awka

\section{*Obiageli Anyaegbu, PhD}

Department of English Language and Literature, Nnamdi Azikiwe University, Awka 
Nnyigide \& Anyaegbu: Teaching and Learning English in a Second Language

\section{Works Cited}

Situation...

Azikiwe, Uche. Language Teaching and Learning. Onitsha: Africana- FEP Publishers Limited, 1998.

Anyadiegwu, Juastina and Obiokoye Amandianaeze. Principles of Teaching English as a Second Language. Onitsha: D-Bell Graphics Press, 2009.

Banjo, Ayo. West African Studies in Modern Language in Modern Language Teaching and Research. Lagos: National Language Centre, Federal Ministry of Education, 1981.

Corder, S.P. 'Error Analysis, Inter language and Second Language Acquisition'. Linguistics and Language Teaching Abstracts, P.201- 218. 1998.

Croft, Kenneth (ed) Readings in English as a Second Language. Cambridge Massachusetts: Winthrop Publishers, 1980.

Eyisi, Joy. A Grammar of English: The Student's Companion. Nimo: Rex Charles and Patrick Ltd, 2006.

---. Teaching of English in Nigerian Schools: Problems, Effects and Remedies" in Ogirisi: a New Journal of African Studies, 2002.

Jowitt, David. Nigerian English Usage: An Introduction. Lagos: Longman Nigeria Plc, 2000

Ellis, Rod and Brian Tomlinson. Teaching Secondary English: A Guide to Teaching English as a Second Language. London: Longman Group Ltd, 1980.

https://en.wikipedia.org/wiki/List_of_universities_in_Nigeria, 2020 